\title{
Rate of endothelial cell loss in the early postoperative period after cataract surgery
}

\author{
N. PRICE, P. JACOBS, AND H. CHENG \\ From the Eye Hospital, Walton Street, Oxford OX2 6AN, and the \\ Nuffield Laboratory of Ophthalmology, Walton Street, Oxford
}

SUMmARY Central corneal endothelial cell density was estimated in 33 consecutive patients preoperatively and at monthly intervals for 6 months after cataract surgery. The patients were divided into 3 groups by a random procedure to have either intracapsular extraction or intracapsular extraction plus Federov 4-loop iris clip lens, or extracapsular extraction with Binkhorst 2-loop iridocapsular lens. In all groups the greatest cell loss had occurred by one month and thereafter no accelerated loss was apparent except in individual patients. The limitations of such a method of assessment are discussed.

Lens implantation has gained in popularity and acceptance in recent years, and over 100000 lens implants are said to be carried out yearly in the United States. Although the short-term efficacy of lens implantation is not in doubt, there are few reports of long-term follow-up. One of the most serious long-term complications is corneal oedema and bullous keratopathy caused by depletion of endothelial cells.

All intraocular procedures produce some cell loss, and even trivial manoeuvres will cause some endothelial cell drop-out. ${ }^{1}$ The early reports of cell loss following lens implantation showed comparatively large amounts of cell loss, ${ }^{2-4}$ but refinements in methods and use of closed chamber techniques have greatly reduced cell depletion. ${ }^{5}$

While it is probable that cell loss is mostly caused by mechanical injury at operation, ${ }^{6}$ endothelial cells are vulnerable to mild trauma. ${ }^{7}$ As it seems likely that a perfect irrigating solution has not yet been found, ${ }^{\mathbf{8 9}}$ surgery, especially extracapsular surgery, which may require irrigation by comparatively large volumes of fluid, could have a long-term effect on the rate of cell loss.

The purpose of this study was to measure central corneal density before cataract surgery and monthly after the operation in an attempt to determine the rate of cell loss after operation and to see whether this differed between 3 different types of surgery.

Correspondence to Dr P. Jacobs, The Eye Hospital, Walton Street, Oxford OX2 6AN.

\section{Material and methods}

Thirty-three patients with uncomplicated senile cataract, already enlisted in a cataract management study, were allocated by a randomisation procedure to have either (1) intracapsular extraction, (2) intracapsular extraction plus Federov 4-loop implant, or (3) extracapsular extraction plus Binkhorst iridocapsular lens implant. In all patients only one eye was operated on, and surgery was carried out by 2 experienced surgeons using standard techniques.

Axial endothelial photographs were obtained with the Nikon noncontact photo-slit camera preoperatively and approximately at monthly intervals for 6 months after surgery. Enlarged prints were made and cell density estimation obtained by the method described previously. ${ }^{10}$ The 33 patients were distributed equally between the 3 groups. Patient compliance was good, and of 231 expected sets of photographs 198 were obtained. Missing data were due to: failure of attendance 19; failure to obtain clear photographs 14 ; total 33 .

The mean number of observations per patient was 6 , and only one patient had fewer than 4 sets of photographs. We aimed to count 3 photographs per visit, and this was achieved in 66 out of the 198 sets, the remaining counts being based on the best 2 photographs. In a small number of cases only one clear photograph was obtained. These are indicated by an asterisk in the accompanying tables. 


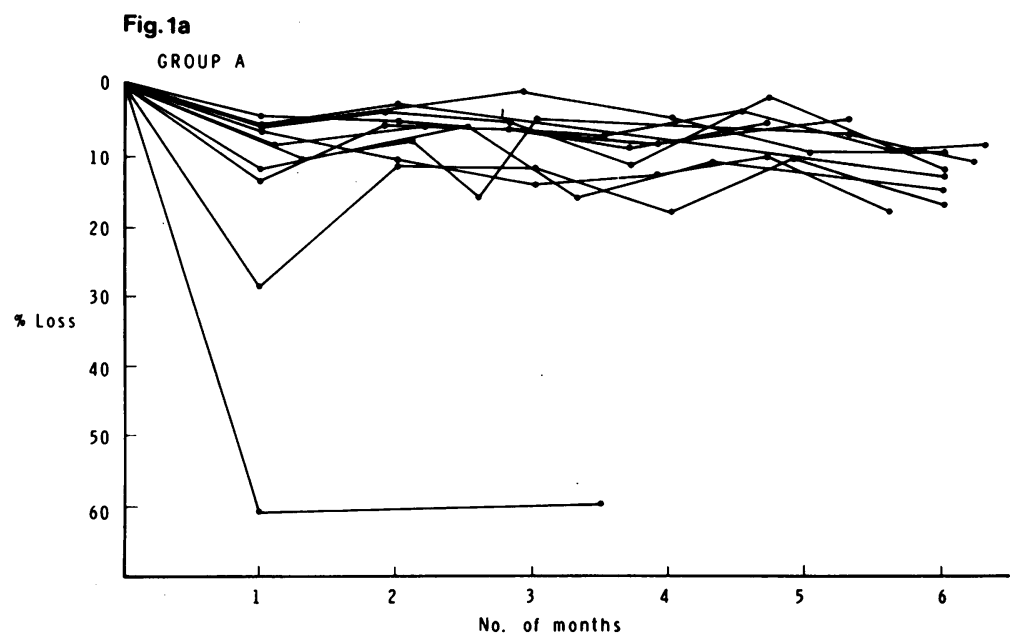

Fig. 1a,b,c Percentage cell loss with time for 3 different treatment groups (each line represents one patient).

Fig. 1b

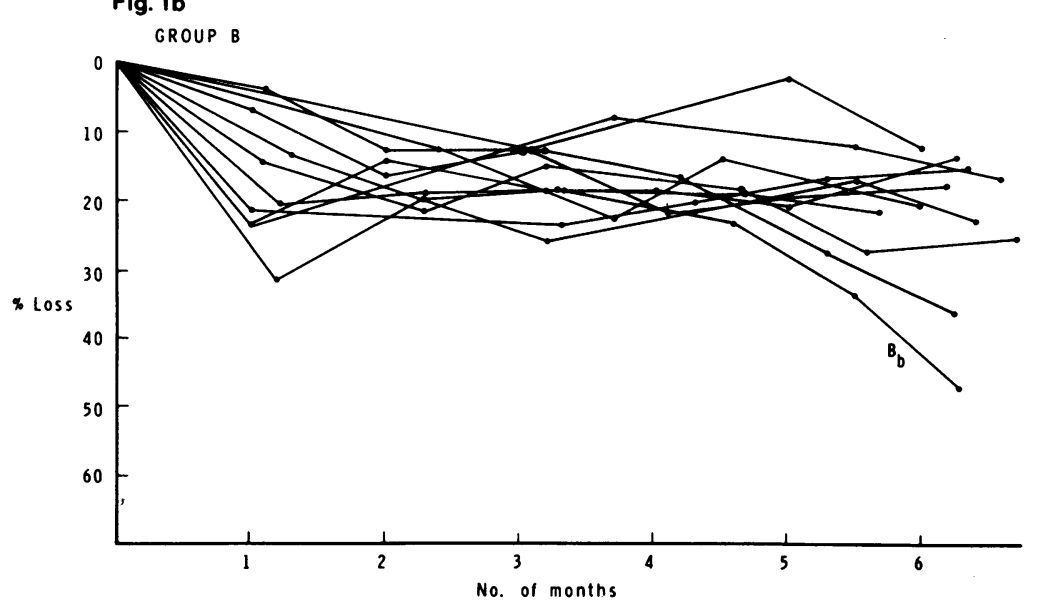

Fig. 1c

GROUP C

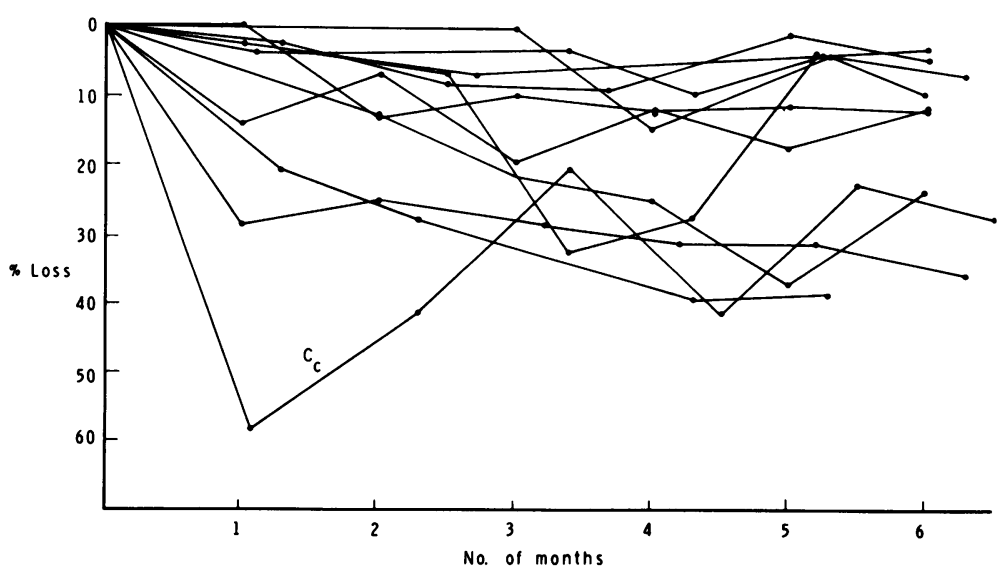




\section{Results and discussion}

The mean axial cell counts for the 3 different treatment groups are shown in Tables 1-3. Each count was expressed as a percentage of the preoperative count for that patient. The percentage loss with time is illustrated by treatment group in Fig. 1 . These results illustrate a number of points. Firstly, cell loss appears to be greater after lens implantation, whether after intracapsular extraction or extracapsular extraction, than after intracapsular extraction alone.

Secondly, although there is wider variation in loss between patients in group $\mathrm{C}$ than in the other 2 groups, it is not clear whether there is any real difference in the mean cell loss between groups B and C.

Although most patients appear to lose cells, in some patients there is a wide fluctuation in estimates from one month to the next. This is particularly marked in group $\mathrm{C}$ (e.g., patient Cc). These fluctuations are too large to be explained by the error inherent in our method of estimation of endothelial cell density. Indeed, if this was the case, one would expect similar fluctuations to be present in all 3 groups.

The most likely cause of the variation is that after operation the cell loss in some patients is unevenly distributed over the cornea. It has been shown ${ }^{1112}$ that in normal eyes endothelial cells are fairly evenly distributed over the cornea even though there may be a small difference in density between the superior and inferior endothelium. ${ }^{13}$ Following surgery cell loss may be uneven, so that closely adjacent regions of the cornea may exhibit widely differing endothelial cell densities. An extreme example is illustrated in Fig. 2. Although we aimed to take axial photographs in each case, it is difficult to ensure that exactly the same part of the cornea is photographed on each visit.

To test this hypothesis we selected one patient from each group and took a series of photographs from above downwards and estimated the cell density. The results are shown in Table 4 . There is a progressive increase in cell density from top to bottom which is

Table 1 Group A, intracapsular cataract extraction, mean cell counts

\begin{tabular}{llllllll}
\hline \multicolumn{7}{l}{ Time interval } & \multicolumn{1}{l}{} \\
\cline { 2 - 7 } Patient & Preop. & 1 & 2 & 3 & 4 & 5 & 6 \\
\hline a & $2573(680)$ & $2420(40)$ & $2510(20)$ & - & - & - & $2260(580)$ \\
b & $2907(440)$ & $1120(200)$ & - & - & $1166(40)$ & - & - \\
c & $2530(100)$ & $2230(120)$ & $2400(220)$ & $2140(260)$ & $2273(220)$ & - & $2170(300)$ \\
d & $2780(20)$ & $2413(140)$ & $2633(120)$ & $2613(120)$ & $2550(20)$ & $2680(40)$ & - \\
e & $2820(80)$ & $2670(60)$ & $2720(40)$ & $2680(80)$ & $2520(40)$ & $2800(80)$ & $2500\left(^{*}\right)$ \\
f & $3010(220)$ & $2706(240)$ & $2786(280)$ & $2547(480)$ & $2880(240)$ & $2820\left(^{*}\right)$ & $2710(20)$ \\
g & $2990(140)$ & $2830(140)$ & - & $2987(100)$ & $2860(160)$ & $2728(80)$ & $2727(227)$ \\
h & $3310(20)$ & $3110(100)$ & $2973(120)$ & $2860(0)$ & $2900(120)$ & $3000(80)$ & $2730(220)$ \\
i & $2920(0)$ & $2670(100)$ & $2750(180)$ & $2730(60)$ & $2833(360)$ & $2680(120)$ & $2700(200)$ \\
j & $2710(140)$ & $2600(100)$ & $2580(40)$ & - & $2500\left(^{*}\right)$ & $2600(80)$ & - \\
k & $2610(100)$ & $1870(20)$ & $2320(0)$ & $2320(40)$ & $2147(20)$ & $2351(360)$ & $2190(100)$ \\
\hline
\end{tabular}

Figures in brackets indicate the range (i.e., difference between the highest and lowest estimations) on which the mean is based.

*Estimate based on only one count.

Table 2 Group B, intracapsular cataract extraction plus Federov II implant, mean cell counts

\begin{tabular}{|c|c|c|c|c|c|c|c|}
\hline \multirow[b]{2}{*}{ Patient } & \multicolumn{7}{|c|}{ Time interval } \\
\hline & Preop. & 1 & 2 & 3 & 4 & 5 & 6 \\
\hline $\mathbf{a}$ & $2910(100)$ & $2220(40)$ & - & - & $2690(260)$ & $2580(120)$ & $2420(120)$ \\
\hline b & $2450(140)$ & $1680(280)$ & 1970 (180) & $2000(320)$ & $1887(200)$ & $1620(80)$ & $1280(40)$ \\
\hline c & $2440(160)$ & - & $2140(80)$ & $1900(320)$ & $2107(180)$ & - & $1930(60)$ \\
\hline d & $3427(360)$ & $2700(40)$ & - & $2620(280)$ & $2740(40)$ & $2870(100)$ & $2900(40)$ \\
\hline e & $1800(40)$ & $1430(100)$ & $1460(160)$ & $1470\left(^{*}\right)$ & $1460(120)$ & - & $1410(60)$ \\
\hline f & $3050(220)$ & $2606(340)$ & $2400(160)$ & $2600(120)$ & $2490(180)$ & $2220(40)$ & 2280 (80) \\
\hline g & $2400(80)$ & $2240(60)$ & $2013(60)$ & $2090(140)$ & - & $2360(40)$ & $2120(200)$ \\
\hline h & $3180\left(^{*}\right)$ & - & - & $2790(60)$ & $2500(0)$ & $2547(140)$ & $2610(60)$ \\
\hline i & $2680(120)$ & $2327(140)$ & - & $1990(60)$ & - & $2230(100)$ & $2070(100)$ \\
\hline j & $2753(200)$ & $2100(120)$ & $2370(100)$ & $2240(160)$ & $2240(240)$ & $2180(40)$ & $2380(0)$ \\
\hline k & $2610(60)$ & $2510(20)$ & $2290(20)$ & $2293(140)$ & $2170(220)$ & $1890(140)$ & $1660(160)$ \\
\hline
\end{tabular}

See footnotes to Table 1 . 
Table 3 Group C, extracapsular cataract extraction plus iridocapsular implant, mean cell counts

\begin{tabular}{|c|c|c|c|c|c|c|c|}
\hline \multirow[b]{2}{*}{ Patient } & \multicolumn{7}{|c|}{ Time interval } \\
\hline & Preop. & 1 & 2 & 3 & 4 & 5 & 6 \\
\hline $\mathrm{a}$ & $2930(20)$ & $2860(40)$ & $2690(140)$ & - & $2670(20)$ & $2900(80)$ & $2800(200)$ \\
\hline b & $2930(140)$ & $2520(160)$ & $2740(200)$ & $2353(180)$ & $2587(80)$ & $2430(20)$ & $2587(100)$ \\
\hline c & $2390(100)$ & $987(80)$ & $1393(180)$ & $1907(160)$ & $1393(200)$ & $1853(53)$ & $1733(160)$ \\
\hline d & $3307(110)$ & $3310(20)$ & $2870(20)$ & $2980(40)$ & $2920(120)$ & $2933(140)$ & $2910(60)$ \\
\hline $\mathrm{e}$ & $2520(200)$ & - & $2200\left({ }^{*}\right)$ & $1973(400)$ & $1890(60)$ & $1586(240)$ & $1930(100)$ \\
\hline f & $3460(340)$ & $2747(160)$ & $2500(120)$ & - & $2100(160)$ & $2133(200)$ & - \\
\hline g & $2610(20)$ & 一 & - & $2610(60)$ & $2240(240)$ & $2510(20)$ & $2360(80)$ \\
\hline $\mathrm{h}$ & $2247(80)$ & $1607(20)$ & $1680\left({ }^{*}\right)$ & $1610(20)$ & $1527(60)$ & $1527(20)$ & $1441(100)$ \\
\hline $\mathrm{i}$ & $2330(100)$ & $2270(20)$ & - & $2173(100)$ & - & - & $2268(0)$ \\
\hline $\mathrm{j}$ & $2807(160)$ & $2740(200)$ & $2633(320)$ & $1900(180)$ & $2033(40)$ & $2710(300)$ & - \\
\hline $\mathrm{k}$ & $2840(40)$ & $2740\left({ }^{*}\right)$ & - & $2750(220)$ & $2580(160)$ & $2730(140)$ & $2650(20)$ \\
\hline
\end{tabular}

See footnotes to Table 1 .

consistent with the findings of Hoffer ${ }^{12}$ for cataract patients. The differences detected are great enough to explain the intrapatient fluctuations. When these fluctuations are taken into account, it appears that most of the cell loss occurs soon after surgery, probably within the first month. There is no clear evidence of continuing cell loss except in the case of one patient, $\mathrm{Bb}$. This was the only case in this series with a major complication. The wound opened 3 weeks after surgery, with loss of the anterior chamber and prolonged contact of the implant with the endothelium. Although this was satisfactorily repaired and the anterior chamber reformed, this patient has continued to lose cells at a rapid rate. The reason for this is not clear.
Table 4 Cell density in 3 eyes: in descending order vertically from top to bottom of cornea. Top=midway from centre to upper limbus at $12 o^{\prime}$ clock; bottom=lowest picture between centre and limbus at $6 o^{\prime}$ clock

\begin{tabular}{llll}
\hline & $\begin{array}{l}\text { Patient Ah in } \\
\text { group } A\end{array}$ & $\begin{array}{l}\text { Patient Bb in } \\
\text { group B }\end{array}$ & $\begin{array}{l}\text { Patient Cc in } \\
\text { group C }\end{array}$ \\
\hline Top & 1920 & 426 & 880 \\
& 2120 & 439 & 980 \\
& 2980 & 466 & 920 \\
Middle & 2980 & 519 & 1140 \\
& 2920 & 453 & 1440 \\
& 2840 & 519 & 1740 \\
& 2900 & 453 & 1660 \\
& 2880 & 466 & 2400 \\
Bottom & 3000 & 439 & \\
\hline
\end{tabular}

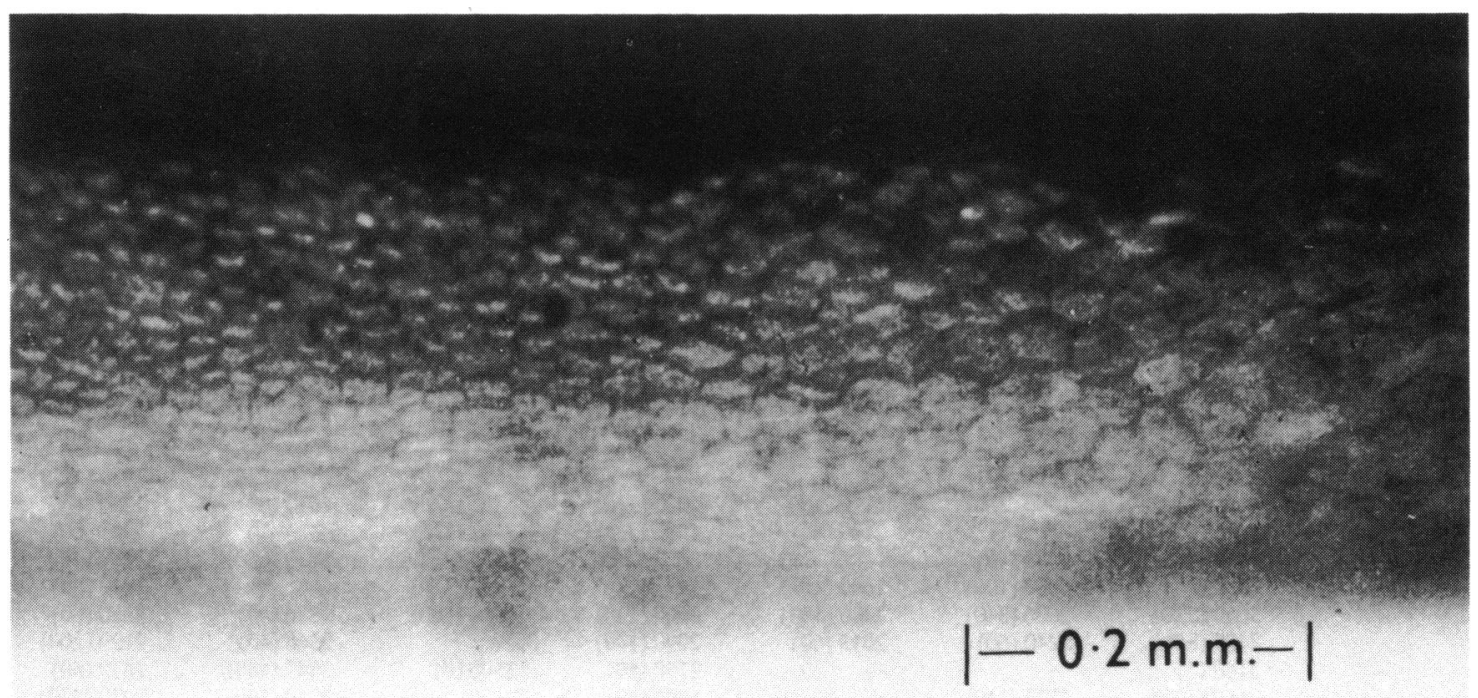

Fig. 2 Axial endothelial cell photograph from a patient following intracapsular cataract extraction, to illustrate variation in endothelial cell density within a short distance across the cornea. 


\section{CONCLUSIONS}

The fluctuations in cell counts from month to month shown by some patients illustrate one of the difficulties of obtaining meaningful estimates of endothelial cell density. Evidence based on only one postoperative count should be interpreted with caution.

Our data also indicate that most cell loss occurs within the first month after surgery. This emphasises the importance of good technique to avoid endothelial cell damage at the time of surgery. Whether there is continuing cell loss over a longer period, or whether there is a difference in cell loss with different types of extraction and lens implant, are important questions that are not answered by the present study. With longer follow-up of larger groups of patients this information should become available.

We are grateful to Mr D. Barbour for photographic assistance and Mrs M. Platts for secretarial help.

This paper is supported by the National Institutes of Health. USA grant no. EYO 2677-03.

\section{References}

1 Galin MA. Fetherolf E, Lin LL. Sugar A. Experimental cataract surgery. Ophthalmology 1979; 86: 213-8.
2 Bourne WM, Kaufman HE. Endothelial damage associated with intraocular lenses. Am J Ophthalmol 1976; 81: 482-5.

3 Sugar J, Mitchelson J, Kraff M. Endothelial trauma and cell loss from intraocular lens implantation. Arch Ophthalmol 1978; 96: 449-50.

4 Cheng H, Sturrock GD, Rubenstein B, Bulpitt CJ. Endothelial cell loss and corneal thickness after intracapsular extraction and iris clip lens implantation. Br J Ophthalmol 1977; 61: 785-90.

5 Hirst LW, Snip RC. Stark WJ, Maumenee AE. Quantitative corneal endothelial evaluation in intraocular lens implantation and cataract surgery. Am J Ophthalmol 1977; 84: 775-80.

6 Galin MA. Lin LL, Fetherolf E, Obstbaum SA, Sugar A. Time analysis of corneal endothelial cell density after cataract extraction. Am J Ophthalmol 1979; 88: 93-6.

7 Sherrard ES. The corneal endothelium in vivo: its response to mild trauma. Exp Eye Res 1976; 22: 347-57.

8 Edelhauser HF, Van Horn DL, Schultz RO, Hyndiuk RA. Comparative toxicity of intraocular irrigating solutions on the corneal endothelium. Am J Ophthalmol 1976; 81: 473-81.

9 Graham MV. Hodson S. Intraocular irrigating and replacement fluid. Trans Ophthalmol Soc UK 1980; 100: 282-5. replacement fluid. Trans Ophthalmol Soc UK 1980; 100: 282-5.

10 Price NC, Cheng $\mathrm{H}$. Contact and non-contact specular microscopy. Br J Ophthalmol 1981; 65: 568-74.

11 Blackwell WL. Gravenstein N, Kaufman HE. Comparison of central corneal endothelial cell numbers with peripheral areas. Am J Ophthalmol 1977; 84: 473-6.

12 Hoffer KJ. Vertical endothelial cell disparity. Am J Ophthalmol 1979; 87: 344-9.

13 Azen SP. Smith RE. Burg KA, Reinig J. Variation in central and vertical endothelial cell density in normal subjects. Acta Ophthalmol (Kbh) 1981; 59: 94-9. 